\title{
Anti-erosion protection for recreational and sports facilities
}

\author{
Elena Shcherbina ${ }^{1 *}$ and Marina Afonina ${ }^{1}$ \\ ${ }^{1}$ Moscow State University of Civil Engineering, 12933, Yaroslavskoe shosse, 26 Moscow, Russia
}

\begin{abstract}
Development of natural lands for recreational purposes generates an increasing human impact. The monitoring results show development of slope erosion processes on the surface of slopes, which can generate gullies and landslides, impeding a sustainable land development and requiring additional operational costs at recreational and sports facilities. The article contains the basic results of a theoretical and experimental research and the monitoring data, which will allow us to justify the design of anti-erosion protection at recreational and sports facilities. The research has shown the efficiency of the use of geocomposite systems represented by a combination of structural elements and a biotic constituent. The efficiency of such approach is proven by the geotechnical monitoring data on specific facilities situated in Moscow Region.
\end{abstract}

\section{Introduction}

The growing rates of urbanization require a new dynamic development of recreational areas for satisfying the people's social need for recreation, sports, tourism and entertainment, and for ensuring a sustainable land development. Architecture and construction always respond quite quickly to the current social needs [1,2], which, for example, is shown, today, by the development of recreational areas of the Moscow agglomeration.

Winter sports, such as skiing and snowboarding are gaining popularity. Ski recreation is a combined type of recreation, which includes recreational, amateur-sports, therapeutic tourism and ecotourism. In Moscow region, there are large areas with all natural conditions for the development of recreational, for example, Dmitrovsky district. Rich forest vegetation combined with varied landscape and favorable natural and climatic conditions allow to create a high-performance resort and recreation system, including large-scale facilities of ski and other complexes, in Dmitrovsky district, Moscow Region. The Moscow agglomeration includes the total of more than 20 ski complexes.

Landscape, free space and access to transport $[3,4]$ are very important for selecting a location for recreational and sports complexes. Taking into consideration the high urbanization of the Moscow agglomeration, the natural areas and areas affected by business activity are used for such facilities, for example, the Fox Lodge sports-shooting complex situated on the territory of a depleted pit. Each recreational and sports complex has a set of natural and man-made elements, earth structures, buildings, engineering and transport

*Corresponding author: 1ev.scherbina@yandex.ru 
systems. We can speak of the level of popularity and consumer appeal a complex based on its development andvariety of the services rendered $[5,6]$.

Additional soil embankments and excavations, as well as lake dams are created on the territory of ski complexes, allowing to do water sports andto ensure their use in summertime, for example, Sorochany ski complex. Thus, such recreational facilities essentially modify natural areas or areas affected by business activity, becoming a powerful human impact resulting in the generation of secondary natural landscapes where not only degradation, but destruction of the soil and vegetation cover is observed.On an artificial landscape surface, the process of natural regeneration of the vegetation cover is slow, which is determined by natural and climatic conditions.

The monitoring results show that the slopes surface is affected by the development of slope erosion processes, which may generate gullies and landslides (fig.1a,c; fig.2a); the extent of destruction is proportional to the extent of earth structures. Thus, protecting slopes from the development of slope erosion processes is a prerequisite for sustainable land development andan important goal of the land development aimed at the environmental safety $[3,7]$. Based on the on-site survey data, it is established that $58 \%$ of slopes are reinforced by grass sowing, $27 \%$ require soil replacement and grass sowing, $15 \%$ require repair of reinforcement structures.

In order to ensure efficient design of anti-erosion protection,the following main functional tasks have been identified: stabilize the slope surface vegetable soil; create favorable conditions for the root system development; slow down the surface runoff. At present, different technical media are applied for preventing the development of erosion processes, but the experience shows that creating a stable sod layer and planting greenery on the surface, which reduces the flow rate $[9,10,11,12,13]$, remain the most reliable and environmentally friendly one. The implementation of this solution is impeded by a short vegetation period and the lack of fertile layer on the slope surface. In many cases, the slope soil is completely infertile due to insufficient organic components in the composition of soil. In order to plant greenery on such slopes, not only applying a layer of fertile soil with grass seeds, but also stabilizing it is required.

Complex research carried out by MGSU $[14,15,16]$ has established that the use of geocomposite systems is an efficient solution in fighting slope erosion processes.The geocomposite systems are represented by a combination of structural elements and abiotic constituent.The structural elements form a system matrix destined for stabilizing the slope surface soil, seeds and plants and creating favorable conditions for the biocommunity development. The matrix may be made of different construction materials, and the composition of the filler includes the following: soil, fertilizers, a variety of seeds, a binder, etc. The specific design solution, the work and stabilization technology depend on the slope steepness, soils, natural and climatic conditions, and are determined based on the data of the predictive calculations of erosive flow rates and system stability. A building structure combined with biological protection media will ensureepy homeostasis of the generated ecosystem throughout the service life of the facility, which is developed within the concept of phytodesign $[6,17]$ consisting in the combination of live plants with artificial material; the vegetation becomes a constituent part of the structure.

Different versions of anti-erosion protection were approved for use at the Sorochany recreational and sports complex (RSC) founded in 2001, which is situated in the floodplain of the Yakhroma river, on Dmitrov highway, $40 \mathrm{~km}$ away from Moscow, and is a constituent part of the second-order agglomeration area formed along the Savelovo direction of the Moscow Railway, the Dmitrov highway and the Moscow Canal; its area is of about 324 ha.

The ski slopes are made on an artificial hill. Filled soil mainly composed of sand, less often, sabulous, heterogeneous with multiple inclusions of fragments of brick and concrete, 
gravel, construction waste, with loam interbeds, slightly wet, with different density and complexity. The total volume of filled soil is of 2 million $\mathrm{m}^{3}$. The geological structure of the filled hill was determined by 5 engineering and geological sections coinciding with the areas of stabilization work for protecting the artificial filled slope from the development of erosion processes.

Table 1.Types of anti-erosion reinforcement applied at Sorochany RSC.

\begin{tabular}{|l|l|l|l|}
\hline No. & Structure types & $\begin{array}{l}\text { Yearofputting int } \\
\text { service }\end{array}$ & $\begin{array}{l}\text { Stabilization area, } \\
\text { thousands of } \mathrm{m}^{2}\end{array}$ \\
\hline 1 & Wooden structures & $\begin{array}{l}2001 \\
2002\end{array}$ & 18.8 \\
\hline 2 & Biogrids & 2004 & 6.03 \\
\hline 3 & MacMat geogrids & 2004 & 10.553 \\
\hline 4 & Gabion structures & 2004 & 4.674 \\
\hline 5 & Geocells & 2005 & 16.57 \\
\hline
\end{tabular}

The region where Sorochany RSC is situated (Kurovo village, Dmitrovsky district) is characterized as typical for Moscow Region, with excessive soil moistening due to a significant amount of precipitation and little evaporability. During the period of construction and commencement of service, development of slope erosion processes was observed on the slopes, so continuous work on slopes stabilization with the application of different methods (table 1) and monitoring were performed during the period from 2001 until 2006. As the result of the regular work, erosion processes were stopped on all areas (fig.1 B,D), which allowed to ensure the stability of the support structures of lifts, stop the destruction of slopes, improve the aesthetics, ensure the stability of the secondary landscape.

Another facility subject to monitoring is Fox Lodge RSC. Today, it is the largest sportsshooting complex in Russia and Europe. The complex is situated in Gurban, a former sandgravel soil extraction pit which was used during the period from 1982 until 2000; its original area was of 80 ha, the height of the walls was of up to $31 \mathrm{~m}$, the angles of the walls were 28.80 to $32.5^{0}$ [9]. Its territory includes over 20 equipped sport shooting areas, Olympic stands and shooting galleries of 10. 25 and 50 meters. In the 300 meters shooting gallery, the highest-level competitions take place. The complex includes a hotel complex, superb sand beaches, a clean lake, boat and bicycle trips, fishing, gulf, badminton and tennis, restaurants. The sportsmen and the guests move within the territory of the complex by electric cars only. Even deers and roes can be seen here. 
A

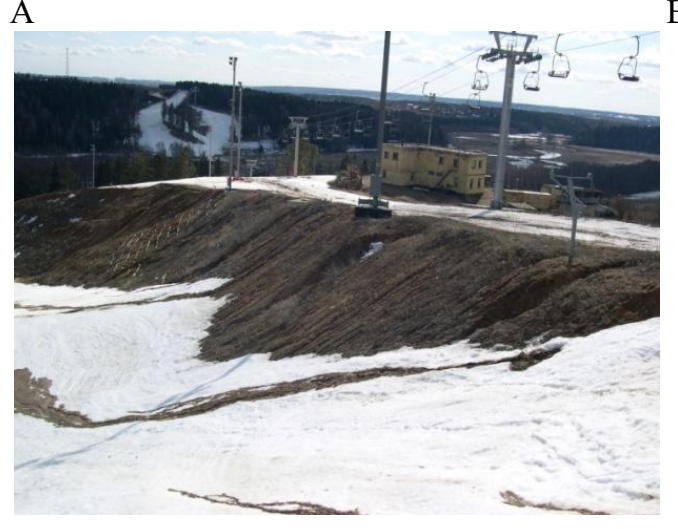

$\mathrm{C}$

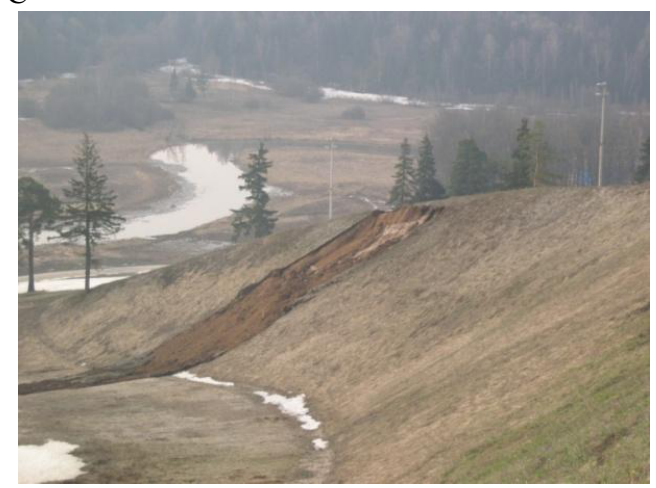

B

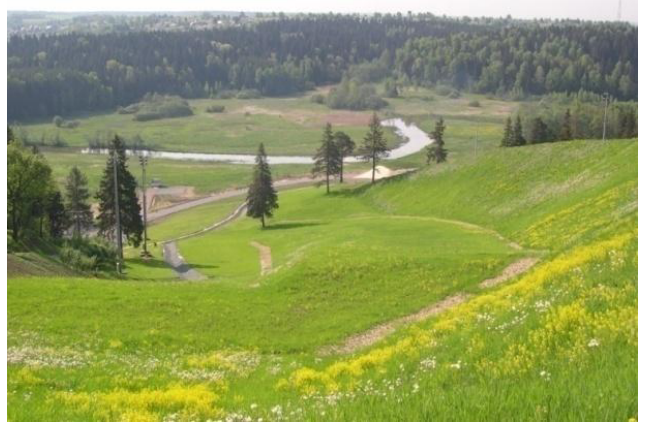

$\mathrm{D}$

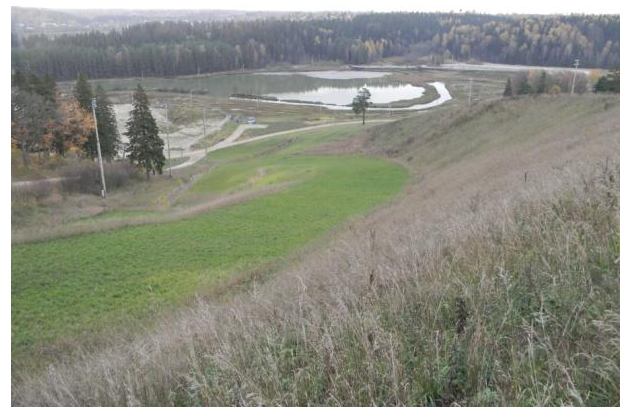

Fig. 1. Sorochany RSC monitoring data. A - one of the slopes before the work on anti-erosion protection (03.2006), B - the first spring after the slope stabilization (05.2007), C -an unexpected landslide (04.2008), D- slope condition in autumn (2011)

The complexity of this facility is due to the fact that it started to form on the territory of a depleted pit with the slopes affected by the development of slope erosion processes (fig. 2 A). According to the calculation data, the slopes were in a stable condition, and the landslides occurred as the result of a water erosion. The anti-erosion protection consisted in a complex of activities, including the following: creating a surface runoff with water discharge into the protected channels of gullies produced, stabilizing the slopes by sowing grass and bushes (fig.2 D). The hillside ditches and the watercourses were protected with the use of geocomposite systems. The system matrix was represented by geosynthetic material, a three-dimensional anti-erosion geogrid with a fiber thickness of $0.5 \mathrm{~mm}$, a porosity of 0.95 , a thickness of $10 \mathrm{~mm}$ and $18 \mathrm{~mm}$ and a tensile strength of $1.8 \mathrm{kN} / \mathrm{m}$ and 1.9 $\mathrm{kN} / \mathrm{m}$ respectively [9]. The filler was represented by soil with grass seeds stabilized with the use of a bituminous binder in the places of watercourses. As the result, the development of erosion processes was stopped the next year after the work was realized (fig. 2B). The results obtained also allowed to justify experimentally the theoretical model allowing to forecast the erosive flow rates for slopes with unbound soils. 
A

B

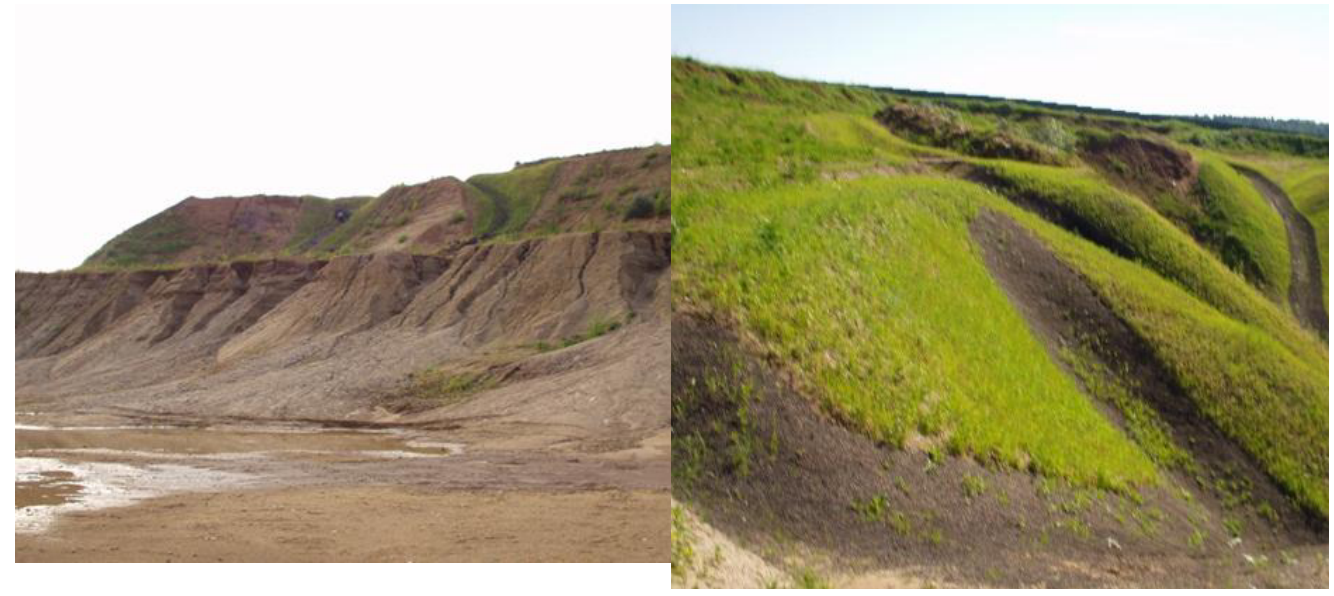

C D

$\mathrm{D}$

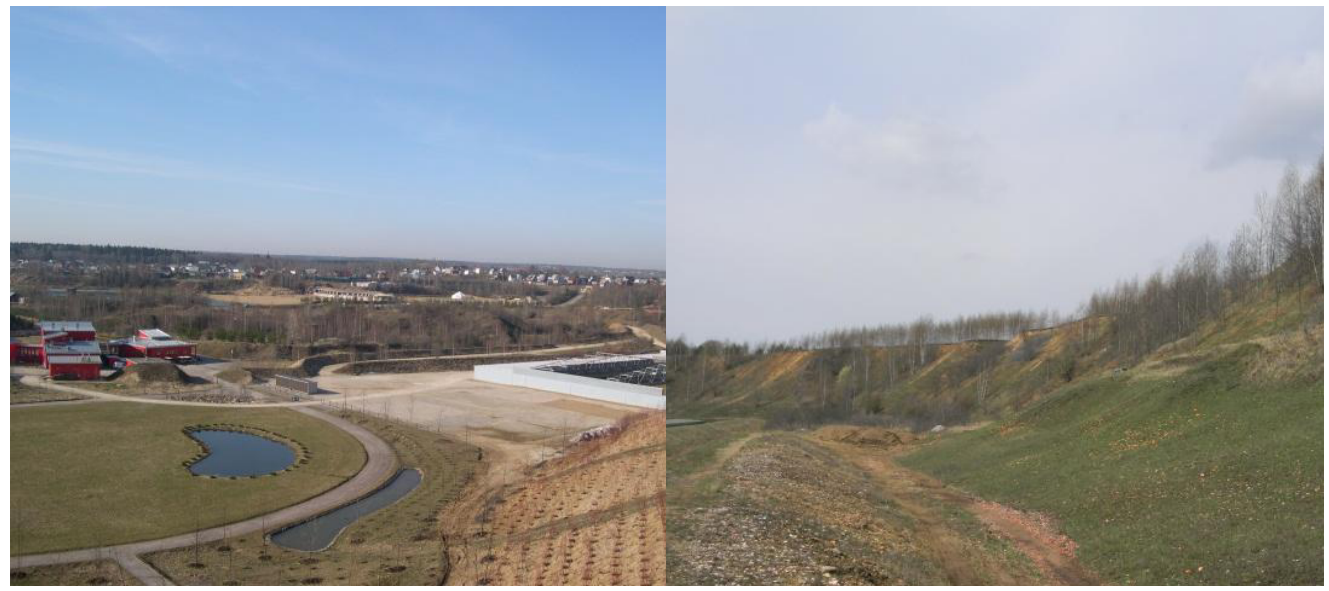

Fig.2 Fox Lodge sports-shooting complex. A - slopes at the commencement of the stabilization work, 2003, B -a fragment of a hillside ditch stabilized with the use of a geocomposite system (2005)C planting bushes on slopes (2007), D - condition of slopes in spring of 2013 (photographs made by the authors).

\section{Conclusions}

The slopes at the sports complexes are stabilized by fulfilling geotechnical activities aimed at preventing the development of slope erosion processes, including the following: the engineering and geological survey; the calculation of the total slope stability; the determination of the critical erosive flow rates; provision of the surface runoff; development of the structure of the geocomposite system; selection of the vegetation type with due regard to the climatic conditions.

Geotechnical monitoring is an indispensable means for providing stable development of recreational and sports complexes; it may also include elements of environmental monitoring, which will allow to ensure environmental safety of the said territory. 


\section{References}

1. V.P. Strauskas, Town-planning organization areas and recreation centers, (1977)

2. M.I. Afonina, M.M. Burova, Proceedings of the international scientific-practical conference "Modern problems and their solutions in science, transport, manufacturing and education 2012". Issue 4 50, 18-23, (2012)

3. M.I. Afonina, Proceedings of the 3rd International Scientific and Practical Conference "Energointegratsiya -2013", (2013)

4. M.I. Afonina, Electronic scientific editions "Naukovedenie", 4 (13), (2012)

5. V.I. Telichenko, V.M. Rojtma, M.J. Slesarev, E.V. Shherbina, Fundamentals of complex safety of construction, (2011)

6. M.I. Afonina, Ecology of the urbanized territories, 81-86, (2008)

7. E.V. Shherbina, M.I. Afonina, M.V. Otchercov, V.N. Shatohin, Proceedings of the Jubilee Conference, devoted to the 50th anniversary RSSMGFE Moscow. (2007)

8. R. Sullivan, Roadside erosion causes and factors: Minnesota survey analysis. 948, 4754, (1983)

9. A.A. Alekseev, Geoecological effectiveness of geokompozitsionnyh screens at restoration of landscapes disturbed by mining activities, (2005).

10. E.V. Shherbina, Geosynthetics in building, (2004)

11. P.A. Slepnev, E.V. Shherbina, The role of long-term strength geosynthetic material in the calculation and design of erosion protection of slopes, (Moscow, Academy. Architecture and Construction, 2010)

12. P.A. Slepnev, Rationale for effective protection against the erosion of the elements of water recreation facilities in the city, (2009)

13. P.A. Slepnev, Hazard assessment of erosion and fluvial processes developing in the ponds and streams in urban areas, 235-237, (2006)

14. L.A. Volodina, P.A. Slepnev, Integration, Partnership and Innovation in Construction Science and Education, 1, 397-399, (2011)

15. M.I. Afonina, Ecology of the urbanized territories, 81-86, (2008)

16. M.I. Afonina, Roads of Russia XXI century H4, (2012)

17. M.I. Afonina, V.V. Balaban, Ecology of the urbanized territories, 75-79, (2013)

18. M.I. Afonina, Research fitokonstruktivnyh modules for the rehabilitation of the urban environment and the development of the technology of their creation and implementation, (2000)

19. M.I. Afonina, A.M. Korobko A.M., Statistical analysis of the influence of climatic factors on the development of a sports and recreation complex "Sorochany", Bulletin MGSU, 5, 24-29, (2011)

20. M.I.Afonina, M.M. Burova, Definition of "Factor attraction" RAC "Sorochany" method kvalimetricheskoj evaluation. Scientific Readings dedicated to the 100th anniversary of Yu.B.Monfreda, 293-299, (2013) 